\title{
Comparative study of age estimation in wild and cultured Octopus vulgaris paralarvae: effect of temperature and diet
}

\author{
C. Perales-Raya ${ }^{1, *}$, M. Nande ${ }^{2}$, A. Roura ${ }^{3}$, A. Bartolomé ${ }^{1}$, C. Gestal ${ }^{3}$, J. J. Otero ${ }^{2}$, \\ P. García-Fernández ${ }^{3}$ E. Almansa ${ }^{1}$ \\ ${ }^{1}$ Instituto Español de Oceanografía, Centro Oceanográfico de Canarias, Santa Cruz de Tenerife 38180, Spain \\ ${ }^{2}$ Instituto Español de Oceanografía, Centro Oceanográfico de Vigo, Vigo 362390, Spain \\ ${ }^{3}$ Instituto de Investigaciones Marinas Consejo Superior de Investigaciones Científicas, Vigo 36208, Spain
}

\begin{abstract}
The common octopus Octopus vulgaris is a highly valuable species worldwide, but to understand its population dynamics and requirements under culture conditions, it is crucial to improve our knowledge about its planktonic stages. Previous studies validating daily beak growth increments in these stages allowed age estimation and comparison of wild and cultured paralarvae. We aimed to improve age estimations in captivity, addressing the effect of temperature and diet, to obtain an accurate estimation of age in wild specimens collected from the coast to the open ocean off NW Spain and Morocco. We analysed the beak growth increments of reared paralarvae at 14 and $21^{\circ} \mathrm{C}$ with 2 different crustacean prey taxa (Artemia and spider crab Maja brachydactyla zoeae) over $30 \mathrm{~d}$. Daily increment deposition at $21^{\circ} \mathrm{C}$ was confirmed, whereas $<1$ increment $\mathrm{d}^{-1}$ was recorded at $14^{\circ} \mathrm{C}$. The width of the reading area grew accordingly with age; therefore, this beak region may be suitable for age estimation. A general linear model (GLM) analysis showed that temperature and the interaction of age $\times$ temperature significantly influenced increment deposition, whereas diet did not. The number of growth rings recorded in wild paralarvae beaks ranged from $0-8$ on the coast, $7-11$ on the continental shelf and 2-28 in the open ocean. Corrected age estimates of wild paralarvae were obtained with the GLM using the mean temperatures recorded in the wild, supporting the hypothesis that $O$. vulgaris leave the coastal area and develop in the open ocean transported by upwelling filaments.
\end{abstract}

KEY WORDS: Octopus vulgaris - Cephalopod - Paralarvae - Early life · Ageing - Beaks · Microstructure $\cdot$ Prey $\cdot$ Growth

\section{INTRODUCTION}

The common octopus Octopus vulgaris Cuvier, 1797 (Cephalopoda, Octopodidae) is a globally important fisheries species with a high economic value (Xavier et al. 2015). Octopuses being exported globally under the name $O$. vulgaris (multiple $O$. vulgaris-like species, Amor et al. 2017) are of extremely high market value in Mediterranean, South American and Asian countries, but especially in north-western Africa, the largest single-species octopus fishery in the world (Norman et al. 2016). Following the decline of tradi-

${ }^{*}$ Corresponding author: catalina.perales@ieo.es

${ }^{\S}$ Advance View was available online September 5, 2017; subsequently updated September 12, 2017

$\S \S$ Email address was corrected after publication. This updated version: May 14, 2019 tional fisheries (Balguerías et al. 2000), cephalopods have gained attention in aquaculture practice.

$O$. vulgaris has great potential for aquaculture diversification since it meets some of the requirements for commercial aquaculture, such as fast growth (Mangold \& Boletzky 1973, Semmens et al. 2004), a short life cycle (Boyle \& Rodhouse 2005), high food conversion rates (Mangold 1983), easy adaptation to captivity (Iglesias \& Fuentes 2014), as well as high demand and market value (Vaz-Pires et al. 2004, Vidal et al. 2014). In addition, it is a valuable experimental animal for biomedical and behavioural

() The authors 2018. Open Access under Creative Commons by Attribution Licence. Use, distribution and reproduction are unrestricted. Authors and original publication must be credited. 
research (Hochner 2008), and is affected by the requirement of the new European Directive 2010/ $63 / E U$ which regulates the welfare and use of animals for scientific purposes, minimizing the use of wild animals to be used in experimentation. The species has a planktonic paralarval stage in its early life (Villanueva \& Norman 2008), which is critical for the success of both cultured and wild populations.

In captivity, massive mortality during the paralarval stage of the common octopus is the main bottleneck for its commercial exploitation (Iglesias \& Fuentes 2014). Based on feeding trials with enriched live food and natural zooplankton, several authors have suggested that this mortality could be caused, to some extent, by nutritional deficiencies in the paralarvae (Navarro et al. 2014). In addition, expression analysis of selected genes suggests an effect of environmental stress on the immune competence of the paralarvae, which could negatively affect their health and welfare (Castellanos-Martínez \& Gestal 2013). Therefore, better knowledge about nutritional requirements, physiology and health status of wild specimens could help to identify the causes of the high mortalities under culture conditions.

Difficulties in studying the planktonic early stages in their natural environment are mostly related to their scarcity, due to the high dispersion of wild paralarvae together with the seasonality of the spawning period (Otero 2006). In the first days post-hatching, paralarvae inhabit the coastal area, but they move away towards the oceanic platform and open ocean in the later ages prior to benthic settlement (Roura et al. 2016). These difficulties of sampling, together with the complexity of age estimation in wild paralarvae has prevented the accurate study of paralarval development and the comparative analysis of wild and cultured paralarvae of similar ages (Garrido et al. 2016a). This comparative approach is of great interest to understand the ecology and feeding of planktonic stages in their natural environment (Villanueva \& Norman 2008), which could serve as a guide to establish requirements for these early developmental stages under culture conditions.

Regarding age estimation, Hernández-López et al. (2001) studied daily formation of growth increments on the lateral walls of the beaks of cultured $O$. vulgaris paralarvae up to $26 \mathrm{~d}$ old. Recently, PeralesRaya et al. (2014b) validated daily deposition using the anterior coloured region of the upper jaw, where parallel and thin increments were observed, broadening the range of paralarvae and transition-to-settlement individuals up to $98 \mathrm{~d}$ old. These findings allow us to refine the study of wild paralarvae throughout their development as well as to compare wild and cultured individuals of similar age. Age estimation in the anterior coloured region of the upper jaw has been successfully used in wild paralarvae together with a characterization of fatty acid composition (Garrido et al. 2016a) and identification of potential rearing stress in octopus paralarvae (Franco-Santos et al. 2016). Age validation experiments in these studies were carried out at $19-23^{\circ} \mathrm{C}$, within the range of optimal temperature $\left(21^{\circ} \mathrm{C}\right)$ under culture conditions (Hamasaki \& Morioka 2002, Iglesias et al. 2014). However, no studies have been carried out at thermal conditions of the natural environment of the paralarvae, where the temperature is usually lower $\left(12-14^{\circ} \mathrm{C}_{i}\right.$ Roura et al. 2016). Development in cephalopods is greatly affected by the environmental temperature, as has been shown in $O$. vulgaris paralarvae, in which growth rate increases proportionally to the water temperature (Hamasaki \& Morioka 2002).

The aim of the present study was to estimate, for the first time, the ages of wild coastal and oceanic paralarvae by counting the parallel thin increments (rings) observed in the anterior region of the upper jaw. Wild samples collected in coastal and oceanic waters off NW Spain and Morocco were analysed and compared with reared individuals. As a first step, captive paralarvae were maintained under different conditions to assess the potential effect of temperature and diet on the increment deposition. Individuals were cultured at the conventional rearing temperature $\left(21^{\circ} \mathrm{C}\right.$, Iglesias \& Fuentes 2014) and at the lowest range of the thermal conditions in coastal environments (around $14^{\circ} \mathrm{C}$ ). As diet is among the most important factors affecting paralarval growth, the effect of 2 different prey was compared: Artemia and spider crab Maja brachydactila zoeae, which are closer to their natural prey (Roura et al. 2012) and support better growth relative to Artemia (Reis et al. 2015, Garrido et al. 2016b). Our aim was to improve age estimations of $O$. vulgaris at early stages, addressing the effect of temperature and diet under culture conditions. This information was then used to interpret the age estimated in wild $O$. vulgaris paralarvae collected in 3 different locations throughout their planktonic stage (coast, continental shelf and open ocean) in 2 upwelling ecosystems.

\section{MATERIALS AND METHODS}

\section{Culture of paralarvae}

Two rearing experiments with Octopus vulgaris paralarvae were carried out at similar conditions 
using 2 different temperatures and diets: the first at $21^{\circ} \mathrm{C}$ (optimal temperature under culture conditions, Iglesias \& Fuentes 2014), and the second at $14^{\circ} \mathrm{C}$ (similar to environmental temperature in coastal waters of Ría of Vigo, NW Spain). For each temperature, 2 different diets were tested, i.e. Artemia and zoeae of the spider crab Maja brachydactyla.

\section{Octopus broodstock}

Thirteen female and 5 male $O$. vulgaris were captured in January 2015 for the first experiment, whereas 5 females and 2 males were captured in January 2016 for the second experiment. In both cases, artisanal fishing gear was used. Octopus broodstock was maintained in a concrete tank (4.60 $\times$ $2.10 \mathrm{~m}$ ) with $1.0 \mathrm{~m}$ of water depth. Broodstock was fed 3 times a week with frozen mussels Mytilus galloprovincialis, frozen fish (Merluccius merluccius and Sardina pilchardus) and frozen crustaceans (Polybius sp.). Several plastic pipes $(0.2 \mathrm{~m}$ diameter, $0.5 \mathrm{~m}$ length) were placed into the tank as dens for females to spawn. During spring, females began to lay their eggs into the dens independently. Egg batches were placed into the plastic pipes so the clusters remained suspended and the female could clean and constantly oxygenate them with gentle water jets from the funnel. Spawning females were transferred from the broodstock tank and placed in smaller tanks $\left(1 \mathrm{~m}^{3}\right)$ individually with low light intensity (<100 lux). The embryonic development of $O$. vulgaris lasts from 45 to $65 \mathrm{~d}$, depending on incubation temperature (14 and $18^{\circ} \mathrm{C}$ respectively; Nande et al. 2017). Broodstock and isolated females were maintained in a flow-through system at the natural environment temperature of the Ría of Vigo $\left(14-18^{\circ} \mathrm{C}\right)$, salinity at 35 psu (Refractometer ATC, ATAGOO) (Iglesias et al. 2016), dissolved oxygen at around $8 \mathrm{mg} \mathrm{l}^{-1}$ (OxyGuard-10XHM053, Polaris( $)$ and ammonia, nitrites and nitrates close to 0 (kit Nutrafin@). Temperature and oxygen were measured daily, whereas salinity and nitrogen were monitored once a week.

\section{Spider crab broodstock}

From January to April in 2015 and 2016, 81 spider crabs were maintained in $1 \times 1 \mathrm{~m}$ tanks with seawater depth of $0.8 \mathrm{~m}$, in an open flow-through system and at ambient temperature of the Ría of Vigo $\left(14-18^{\circ} \mathrm{C}\right)$. Light intensity was low (<100 lux). Crabs were fed 3 times per week with frozen mus- sels $M$. galloprovincialis. The maturation stage was evaluated each week, and the females were reorganised into tanks with similar developmental stages (Iglesias et al. 2014). Spontaneous hatchlings were collected using a $500 \mu \mathrm{m}$ sieve and transferred to $100 \mathrm{l}$ tanks at $14^{\circ} \mathrm{C}$ and closed-circuit water circulation.

\section{Octopus paralarvae rearing}

O. vulgaris hatchlings were removed from the incubation tank $12 \mathrm{~h}$ before the beginning of the rearing experiments to ensure that only newly hatched paralarvae were used. In both experiments (21 and $14^{\circ} \mathrm{C}$ ), 6 paralarvae $1^{-1}$ were transferred into 2 fibreglass cylindrical tanks of 5001 with black bottoms, soft central aeration, temperature at $21 \pm 1^{\circ} \mathrm{C}$ and 14:10 h light:dark photoperiod with an intensity of 250-300 lux at the surface. During the first $5 \mathrm{~d}$ post hatching (dph), they were kept in a closed-circuit system, daily controlling the levels of nitrites, nitrates and ammonia (close to 0), after which paralarvae remained in an open circuit for $5 \mathrm{~h}$ with a flow of $3.51 \mathrm{~min}^{-1}$, achieving 2 total renovations. Two types of microalgae, Isochrysis galbana (Ig) and Nannochloropsis gaditana (Nn) were added daily at a final concentration of 150000 and 500000 cells mler , respectively. The paralarvae were fed with spider crab zoeae at a concentration of $0.02 \mathrm{ml}^{-1}$ and Artemia metanauplii (enriched at $25^{\circ} \mathrm{C}$ during $24 \mathrm{~h}$ with $\mathrm{Ig}$ and $\mathrm{Nn}_{i}>2 \mathrm{~mm}$ total length) at a final concentration of 0.2 Artemia $\mathrm{ml}^{-1}$. Equivalent methodology was carried out in rearing tanks at low temperature (14 \pm $1^{\circ} \mathrm{C}$ ). For beak analysis, a total of 33 paralarvae (at $21^{\circ} \mathrm{C}$ ) and 50 paralarvae (at $14^{\circ} \mathrm{C}$ ) were collected. Different ages were sampled in each treatment (2-5 paralarvae in each sample). The $21^{\circ} \mathrm{C}$-Artemia group was sampled at 7, 10 and $20 \mathrm{dph}$, and the $21^{\circ} \mathrm{C}$-zoeae group was sampled at 7,10, 20 and $30 \mathrm{dph}$. Paralarvae reared at $14^{\circ} \mathrm{C}$ and fed Artemia were sampled at $5,710,13,15,20$ and $22 \mathrm{dph}$, and the $14^{\circ} \mathrm{C}$-zoeae group was sampled at 12, 15 and $20 \mathrm{dph}$. Paralarvae were anaesthetized with a solution of $1.5 \%$ magnesium chloride in seawater $\left(\mathrm{MgCl}_{2}\right)$ for $10 \mathrm{~min}$ and then killed by increasing the solution to $3.5 \%$ for 30 min (following Fiorito et al. 2015).

\section{Paralarvae dry weight and growth rate}

In order to obtain the dry weight, 10 paralarvae were randomly sampled from the rearing tanks at 0 (hatch- 
lings), 5, 10, 15, 20 and $30 \mathrm{dph}$. Paralarvae were killed as described above. Subsequently, dry weight was obtained for each treatment, using small handmade aluminium baskets, after $24 \mathrm{~h}$ in a dry oven at $80^{\circ} \mathrm{C}$ using an ultra-precision (0.000001 g) UM3 Mettler scale. Paralarval dry weight was used to calculate the standard growth rate (SGR) for each type of diet throughout the rearing period:

$$
\mathrm{SGR}=\frac{\ln \left(\mathrm{PDW}_{\mathrm{f}}\right)-\ln \left(\mathrm{PDW}_{0}\right)}{t_{\mathrm{f}}-t_{0}}
$$

where initial paralarvae dry weight $\left(\mathrm{PDW}_{0}\right)$ and final paralarvae dry weight $\left(\mathrm{PDW}_{\mathrm{f}}\right)$ are the dry weight of the paralarvae at the beginning and end of the rearing experiments; and $t_{0}$ and $t_{\mathrm{f}}$ are the times at the beginning/end of the rearing experiments, respectively.

\section{Wild paralarvae captures}

\section{Coastal paralarvae}

Paralarvae were collected around the Cíes Islands in the Ría of Vigo (NW Spain) (Fig. 1a,b). O. vulgaris paralarvae were classified according to Sweeney et al. (1992). Surveys were carried out in 2015 ( $\mathrm{n}=$ 6) and 2016 ( $\mathrm{n}=5)$ between May and September onboard the RV 'José María Navaz' (Instituto Español de Oceanografía). During each survey, 5 trawls were performed along 2 transects (T1 and T2, Fig. 1b) with a planktonic net of $2 \mathrm{~m}$ diameter and $500 \mu \mathrm{m}$ mesh, to an average depth of $10 \mathrm{~m}$ over 10 min at a speed of 2 knots. Wild paralarvae were sorted on board from zooplankton samples using 301 receptacles. Paralarvae were killed in liquid nitrogen and kept at $-80^{\circ} \mathrm{C}$ until analysis.

\section{Oceanic paralarvae}

Zooplankton samples were collected during the multidisciplinary project 'Canaries-Iberian Marine Ecosystem Exchanges (CAIBEX)', which took place in the seasonal upwelling system off Cape Silleiro $\left(41-43^{\circ} \mathrm{N}\right.$, CAIBEX-I) and the permanent upwelling system off Cape Guir (30-32 $2^{\circ}$, CAIBEX-III). Data acquisition for this study was carried out on board the RV 'Sarmiento de Gamboa' during CAIBEX-I from 7 to 24 July, and CAIBEX-III from 16 August to 5 September (Fig. 1). High-resolution mapping of the study area determined the oceanographic conditions (temperature, salinity and chlorophyll fluorescence) in situ using a towed vehicle (SeaSoar) that undulated between the surface and $400 \mathrm{~m}$ depth. The information collected with the SeaSoar, together with real-time satellite images of sea surface temperature and chlorophyll provided by the Plymouth Marine Laboratory (NERC Earth Observation Data Acquisition and Analysis Service), helped to determine the location of upwelled water masses. Once detected, we followed these upwelled water masses by means of 3 Lagrangian experiments with an instrumented
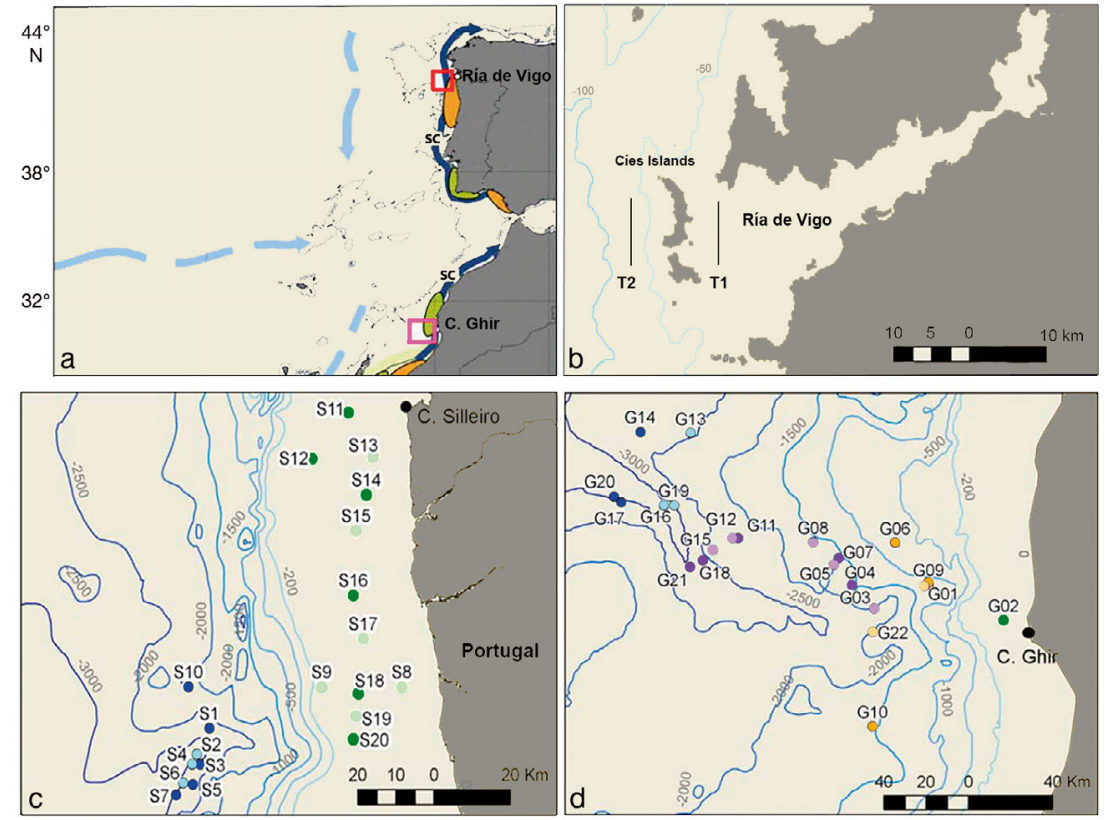

Fig. 1. (a) Iberian-Canary current eastern boundary upwelling system modified from Arístegui et al. (2009), showing the areas sampled (red box: CAIBEX-I cruise, pink box: CAIBEX-III) and the main currents (light blue: surface; dark blue: slope; SC: slope current), retention (orange) and dispersion (green) zones on the shelf. (b) Ría of Vigo (NW Spain) showing the 2 transects (T1 and T2) where 'coastal' Octopus vulgaris paralarvae were sampled. (c) Zooplankton samples collected during CAIBEX-I off the NW coast of the Iberian Peninsula, around Cape Silleiro $\left(42^{\circ} \mathrm{N}\right)$. Blue (green): samples S1-S7 (S13-S20) corresponding to the first (second) Lagrangian experiment carried out in the open ocean (over the continental shelf). (d) Zooplankton samples collected during CAIBEX-III off the NW Africa coast, around Cape Ghir $\left(30^{\circ} \mathrm{N}\right)$. Samples were collected over the continental shelf at night (green, $<200 \mathrm{~m}$ depth), in an area affected by the upwelling in the open ocean (orange, $>200 \mathrm{~m}$ depth), following a coastal upwelling filament during the third Lagrangian experiment (violet) and in the open ocean (blue). Light/dark colours represent day/night samplings 
drifting buoy (IDB) that was deployed in the core of the upwelled water.

Meteorological conditions resulted in only weak development of upwelling during CAIBEX-I. Two Lagrangian experiments were carried out during this survey: (1) oceanic waters over the continental slope were sampled around $41^{\circ} 25^{\prime} \mathrm{N}$ during the relaxation period after a brief upwelling event (L1: 10-14 July, samples S1-S7, Fig. 1C); and (2) an incipient coastal upwelling with alongshore transport over the continental shelf was sampled from 42 to $41^{\circ} 23^{\prime} \mathrm{N}$ (L2: 16-21 July, samples S13-S20, Fig. 1c). Between these 2 Lagrangian experiments, we collected samples following a coastal-oceanic gradient off the Portuguese coast (S8-S10), to see the changes between these 2 environments, as well as 2 samples in the continental shelf of Galicia (S11 and S12). In contrast, strong winds during CAIBEX-III allowed the development of a strong upwelling filament (Sangrà et al. 2015). The IDB was deployed in the core of the upwelling filament, which was advected from the coast into the ocean during the third Lagrangian experiment (L3: 23-31 August, Fig. 1d). Samples were also collected over the shelf (Fig. 1d), in an area affected by the upwelling over the continental slope (Fig. 1d) and in the open ocean (Fig. 1d) to investigate the zooplankton communities surrounding the upwelling filament.

A CTD was deployed to $500 \mathrm{~m}$ depth in the open ocean and to $10 \mathrm{~m}$ above the sea-bottom over the continental shelf $(<200 \mathrm{~m}$ depth) before each zooplankton sampling. Sampling took place close to the IDB both at midnight and midday. Mesozooplankton samples were collected with 2 bongo nets $(750 \mathrm{~mm}$ diameter) equipped with $375 \mu \mathrm{m}$ mesh and a mechanical flow-meter. At a ship speed of 2.5 knots, 3 double-oblique tows were carried out at each station over the continental slope (>200 m depth): at $500 \mathrm{~m}$, $100 \mathrm{~m}$ and at the surface $(0-5 \mathrm{~m})$. Over the continental shelf $(<200 \mathrm{~m}$ depth), samples were collected at $100 \mathrm{~m}$ (or $10 \mathrm{~m}$ above bottom when shallower) and at the surface $(0-5 \mathrm{~m})$. The bongo net was first lowered to the desired depth, towed for $30 \mathrm{~min}$ and subsequently hauled up at $0.5 \mathrm{~m} \mathrm{~s}^{-1}$. It was then cleaned on board and deployed back to the sea for the next towing. In the laboratory, $O$. vulgaris paralarvae were sorted from the zooplankton samples and stored in $70 \%$ ethanol at $-20^{\circ} \mathrm{C}$ (Roura 2013).

\section{Beak analysis}

Cultured and wild paralarvae were analysed for age estimation by counting the parallel thin incre- ments (rings) observed in the anterior region of the upper jaw (beak). The beak of each paralarva (Fig. 2) was extracted under a binocular microscope and pre-
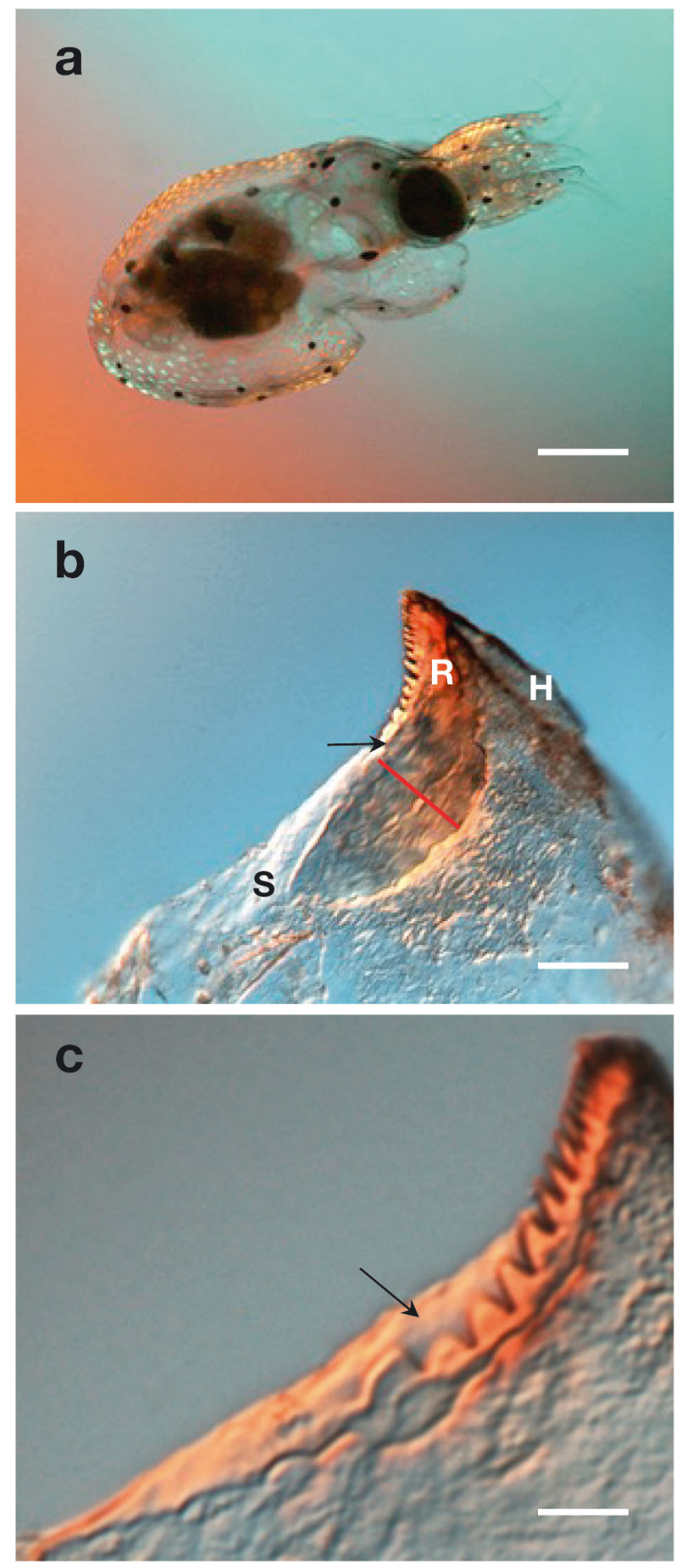

Fig. 2. (a) Lateral view of an Octopus vulgaris paralarva at hatching; scale bar $=500 \mu \mathrm{m}$. (b) Anterior region of the upper jaw beak in a $20 \mathrm{~d}$ old paralarva; location of the main regions (R: rostrum, H: hood, S: shoulder). Arrow: first increment. Red segment: width of the reading area (WRA); scale bar $=50 \mu \mathrm{m}$. (c) Location of the thin line of tissue outside the dentition (arrow) in the upper jaw of a hatchling; scale bar $=50 \mu \mathrm{m}$ 
served in distilled water at $4-5^{\circ} \mathrm{C}$ (Perales-Raya et al. 2010). After longitudinal sectioning of the upper jaw under the binocular microscope, the 2 halves obtained were placed in a slide with a drop of distilled water for observation. Increments in the anterior coloured (pigmented) region of the upper jaw (Franco-Santos et al. 2016) were counted in the half with more clear rings under transmitted light with a Nikon Microscope Multizoom AZ100 (400× magnification). The system has a differential interference contrast attachment (DIC-Nomarski) that creates a 3dimensional image of the beak surface, where the sequence of micro-increments is revealed (Fig. 2b). Two counts were carried out for each paralarva by 2 trained readers. We discarded individuals with more than \pm 1 increments of difference between readings (for paralarvae with 0-7 increments) and individuals with more than \pm 2 increments for other cases (paralarvae with $>7$ increments). The final number of increments assigned to each paralarva was the mean value of both counts. Reading precision (sensu Campana 2001) was assessed with the coefficient of variation $(\mathrm{CV}$, standard deviation divided by the mean number of increments in each sample; Chang 1982, Campana 2001):

$$
\mathrm{CV}(\%)=\frac{100 \times \sqrt{(R 1-R 2)^{2}+(R 2-R)^{2}}}{R}
$$

where $R 1$ and $R 2$ are the number of increments from the first and second reading, respectively, and $R$ is the mean number of increments from both readings. The mean CV was calculated for reared and wild paralarvae in order to assess the reading precision of both groups. For all samples, the width of the reading area (WRA) was measured $(\mu \mathrm{m})$ in the widest region of the reading area, where the increments were counted. After calibration, measurement of WRA (Fig. 2b) was conducted using the Image Analysis System, with the package Image Pro Plus 6.3. (Media Cybernetics 2008). All beaks were preserved in distilled water at least $48 \mathrm{~h}$ before measurements were taken, in order to re-hydrate the microstructure and avoid any differences in the WRA values due to the ethanol (oceanic wild paralarvae). Nonetheless, several samples preserved in $70 \%$ ethanol were measured before and after $48 \mathrm{~h}$ of water immersion, and no difference $( \pm 1 \mu \mathrm{m})$ was found in the WRA value. The number of arm suckers has been used as an approximation of the age and development of paralarvae in previous studies (Villanueva 1995), and these data were also collected in the 165 wild paralarvae analysed.

\section{Statistical analysis}

Results are presented as means $\pm \mathrm{SD}$, and $\mathrm{p}<0.05$ was considered significant. Statistical analyses of linear regressions were performed using the SPSS package version 17.0 (SPSS Inc. 2008). A general linear model (GLM) was applied to test the effect of temperature and diet on increment deposition in captivity. We used temperature and age as linear predictors for the number of increments (NI), with the interaction of age with temperature. Obtained coefficients (intercept, age, temperature and age $\times$ temperature interaction) were used to obtain the equation for age adjustment from NI and a mean temperature value. GLM analysis was performed with $\mathrm{R}$ ver. 3.3.2. (R Core Team 2016) as designed by Hastie \& Pregibon (1992). ANOVA of the GLM fits (analysis of deviance table, Type II test) was performed using the package 'car' (Fox \& Weisberg 2011).

\section{RESULTS}

\section{Improvements in age estimation and beak morphology}

Morphometric analysis of octopus paralarvae beaks provided insight into this structure (Fig. 2). The reading area (named 'lateral hood surface' by Perales-Raya et al. 2014b) is located in the wider part of the anterior coloured (pigmented) region of the beak (Franco-Santos et al. 2016; Fig. 2b). This area corresponds to the rostrum. Adult beaks have the same morphology in this region, but their dense pigmentation makes it more feasible to count increments in the rostrum sagittal section (RSS, after Perales-Raya et al. 2010). The first increment is located at the base of the oral denticles (teeth) (Fig. 2b). The last increment (indicating the day of death) is the posterior border of the reading area, where the rostrum ends and the hood begins. The hood exhibits a delicate and transparent microstructure where no increment sequence was found (see Fig. 2b). We observed a thin line of transparent tissue outside the dentition, extending along the anterior border of the beak. It was identified as part of the developing shoulder (Fig. 2c), which gradually widens through the ventral region with age. To our knowledge, this is the first time that this structure has been identified in paralarvae. Mean reading precision (CV) from the beak readings was $2.97 \pm 2.05 \%$ for individuals cultured at $21^{\circ} \mathrm{C}(\mathrm{n}=33)$ and $3.53 \pm$ $4.32 \%$ for individuals cultured at $14^{\circ} \mathrm{C}(\mathrm{n}=50)$. 
Readings of wild coastal paralarvae showed a mean $\mathrm{CV}$ of $2.94 \pm 5.66 \%$ ( $\mathrm{n}=100)$, and the mean CV obtained from continental-shelf and oceanic paralarvae was $3.83 \pm 4.64 \%(\mathrm{n}=65)$. Although the CV showed high variability, mean values were lower than the usual adopted value of $7.6 \%$ for annual and daily structures (Campana 2001) and therefore no additional paralarvae were discarded based on the $\mathrm{CV}$.

\section{Cultured paralarvae}

The relationship between the number of increments and true age (Fig. 3) in reared paralarvae at both temperatures showed a linear regression for all 4 groups $\left(14^{\circ} \mathrm{C}\right.$-Artemia, $14^{\circ} \mathrm{C}$ zoeae, $21^{\circ}$-Artemia and $21^{\circ} \mathrm{C}$-zoeae). Results of regression analysis are shown in Table 1a. Daily deposition of increments was confirmed at $21^{\circ} \mathrm{C}$, supporting previous validation studies in octopus paralarvae (Perales-Raya et al. 2014b); however, at $14^{\circ} \mathrm{C}$ there was less than 1 increment $\mathrm{d}^{-1}$. These results indicate that in culture conditions, temperature influences the increment deposition in the beak. GLM and ANOVA of the GLM fit with diet included showed that temperature and the factor age $\times$ temperature were highly significant ( $p<0.001)$, but diet was not significant $(p=0.051)$ in the increment deposition and

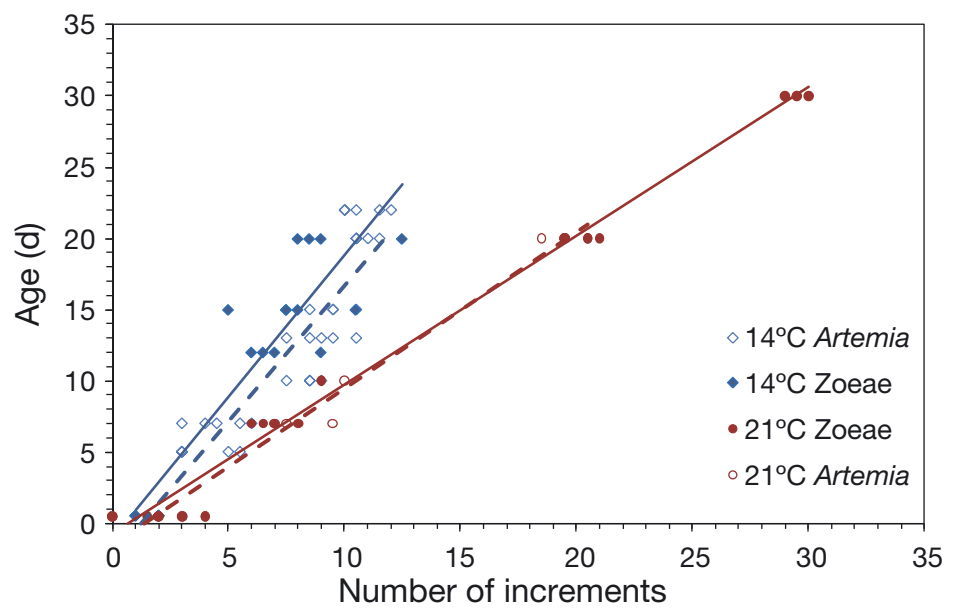

Fig. 3. Relationship between the number of increments in the beak and age of the cultured Octopus vulgaris paralarvae. Data grouped by temperature $\left(14^{\circ} \mathrm{C}, 21^{\circ} \mathrm{C}\right)$ and diet treatments (dashed lines: Artemia; solid lines: spider crab Maja brachydactyla zoeae) consequently, the final GLM was performed without the diet factor. Coefficients obtained from the GLM analysis (Table $1 \mathrm{~b}$ ) resulted in this equation:

$$
\mathrm{AGE}=\frac{\mathrm{NI}-4.604+T * 0.176}{T * 0.074-0.612}
$$

wherewhere NI is the number of increments, $T$ is the temperature, and AGE is the age estimation in days. The highest variability found during the increment readings was for $0 \mathrm{~d}$ paralarvae (hatchlings), showing a mean value of $2.1 \pm 1.52$ increments at $21^{\circ} \mathrm{C}$ and $1.6 \pm 0.55$ increments at $14^{\circ} \mathrm{C}$. Since hatching does not take place at the same time for all eggs within a tank, and some hours have usually elapsed from hatching when the paralarvae are removed from the tank, we assigned $0.5 \mathrm{~d}$ to hatchlings born in culture conditions. Growth of dry body weight (mg) and WRA of the beak $(\mu \mathrm{m})$ in reared paralarvae by temperature and diet are presented in Fig. 4. Paralarvae reared at $21^{\circ} \mathrm{C}$ showed higher weight in the zoeae-fed group than in the Artemia group (Fig. 4a); however, these differences were not observed in the WRA of the beak (Fig. $4 \mathrm{~b})$. These results indicated that the WRA, and by extension the beak, might grow independently of the rest of the body and feeding 

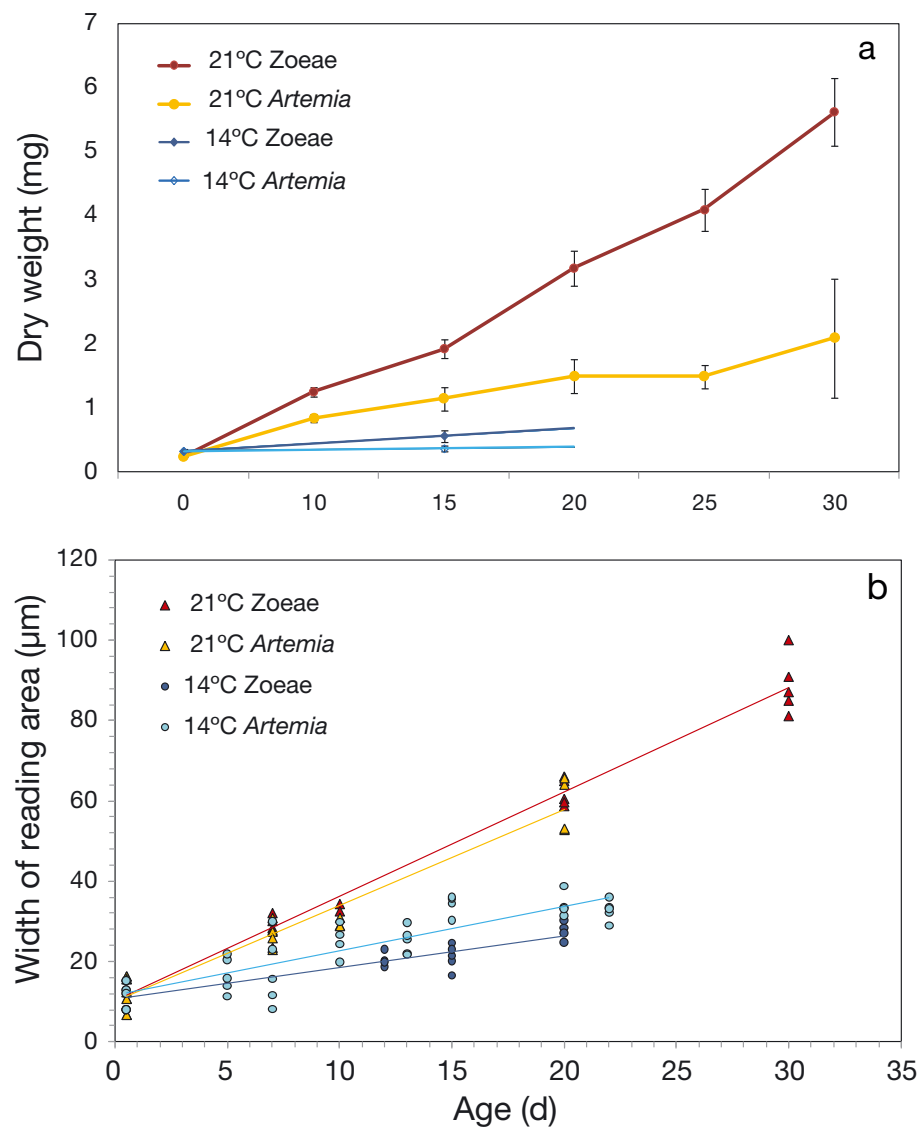

Fig. 4. Growth of cultured Octopus vulgaris paralarvae, with data grouped by temperature and diet treatments (see Fig. 3). (a) Mean growth in dry weight by age group. Data of groups at $14^{\circ} \mathrm{C}$ are extrapolated due to high mortality. (b) Beak growth (width of the reading area; see Fig. 2)

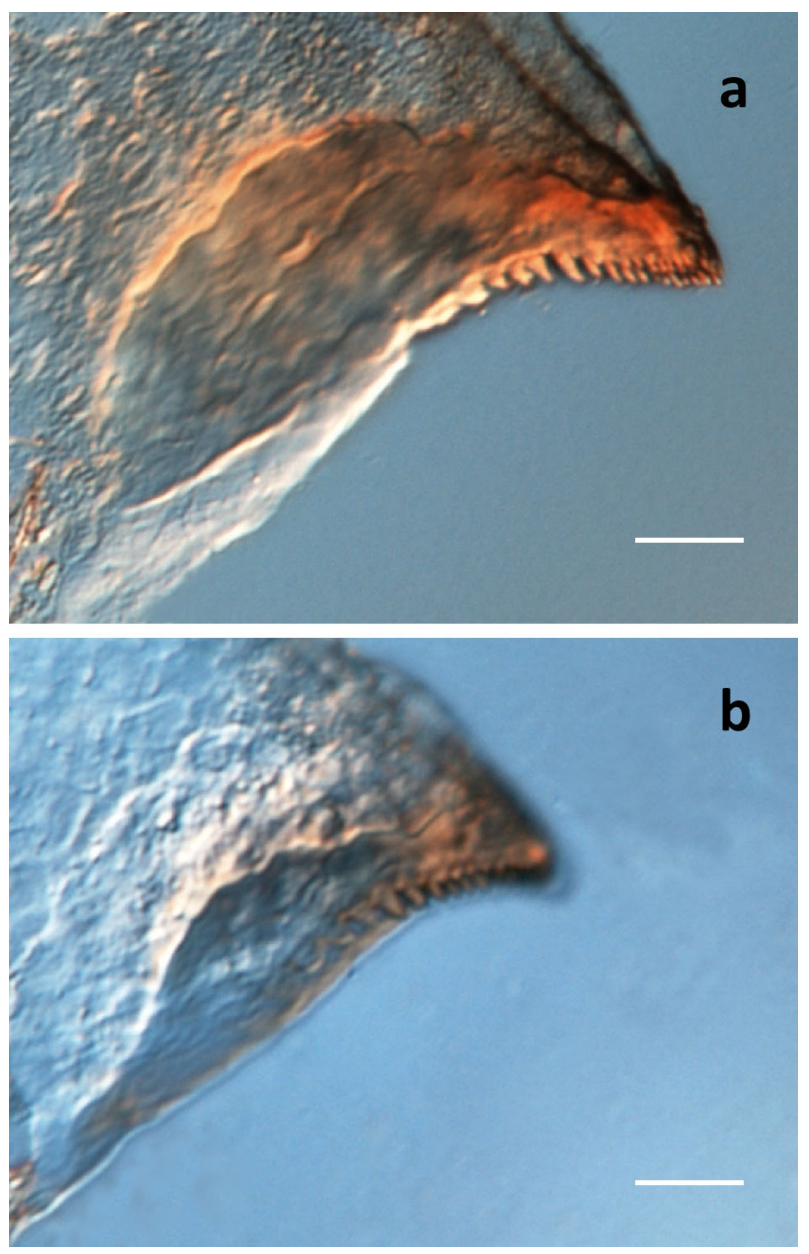

Fig. 5. Beaks of $20 \mathrm{~d}$ old Octopus vulgaris paralarvae, reared at (a) $21^{\circ} \mathrm{C}$ and (b) $14^{\circ} \mathrm{C}$; scale bar $=50 \mu \mathrm{m}$

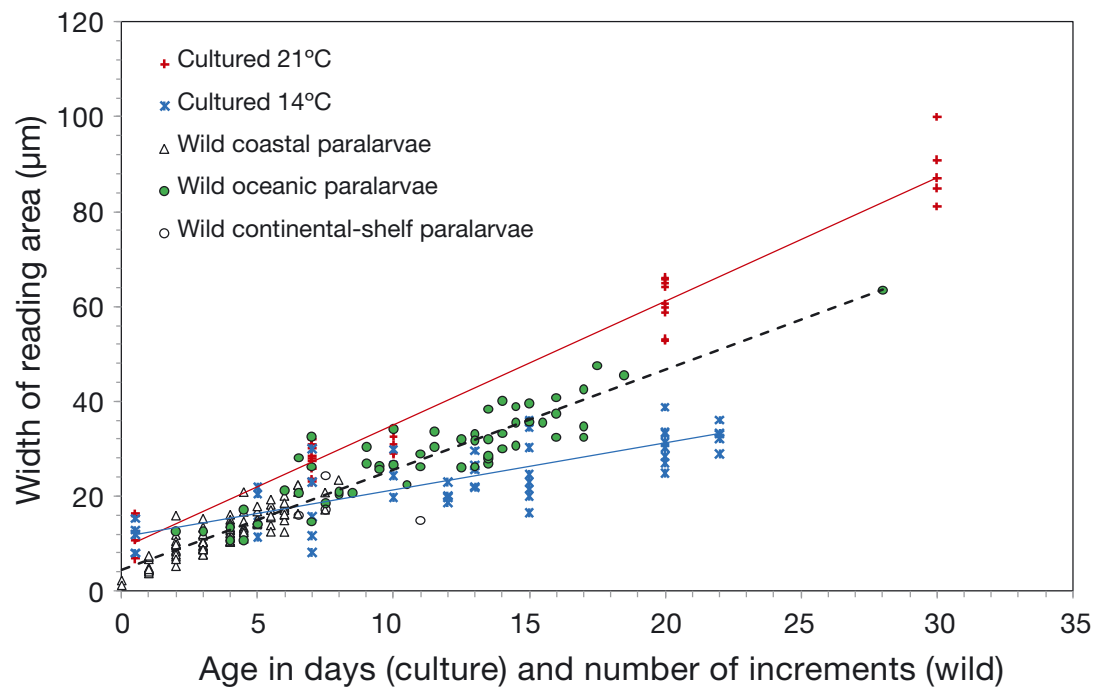

Fig. 6. Growth of the beak (width of the reading area, see Fig. 2) in wild and cultured Octopus vulgaris paralarvae. Cultured samples are grouped by temperature. Age estimation in wild samples = number of increments in the beak assuming daily deposition 
type in culture conditions at $21^{\circ} \mathrm{C}$. In contrast, paralarvae reared at $14^{\circ} \mathrm{C}$ showed a lower growth with similar trends for both dry body weight and beak WRA. Fig. 4b shows that, at similar ages, beaks of paralarvae reared at $14^{\circ} \mathrm{C}$ were smaller than those reared at $21^{\circ} \mathrm{C}$. Two $20 \mathrm{~d}$ old beaks cultured at 21 and $14^{\circ} \mathrm{C}$ are shown in Fig. 5 to illustrate these differences.

\section{Wild paralarvae}

When cultured groups and wild paralarvae are represented using the number of increments as the age estimation (Fig. 6), the highest WRA size resulted for paralarvae cultured at $21^{\circ} \mathrm{C}$ and the smallest for those cultured at $14^{\circ} \mathrm{C}$, with wild specimens showing intermediate WRA values and similar growth trends to paralarvae cultured at $21^{\circ} \mathrm{C}$. Both groups (wild and cultured at $21^{\circ} \mathrm{C}$ ) had also a good linear fit $\left(\mathrm{r}^{2}>0.9\right.$; see Table 1a), evidencing that WRA growth is correlated with age. Results of increment counts in beaks of wild individuals are shown in Fig. 7. The mean NI was 4 increments (range: 0-8) for coastal paralarvae from the Ría of Vigo (all with 3 suckers), 8 increments (range: 7-11) for continental-shelf paralarvae off NW-Spain (3-4 suckers), 12 increments (range: 5-18) in oceanic paralarvae off NW Spain (3-5 suckers) and 11 increments (range: 2-28) in oceanic paralarvae off Morocco (3-15 suckers). Fig. 7 also includes information about the NI range for a given number of suckers. All coastal paralarvae had 3 suckers, as did 3 paralarvae (75\%) from continental shelf NW Spain, 8 paralarvae (22\%) from oceanic waters off NW Spain and 9 paralarvae (38\%) from oceanic waters off Morocco. The latter included the youngest group of oceanic paralarvae (2-7 increments), which were transported from the Moroccan coast by the strong filament followed during CAIBEX-III. Considering the possible influence of temperature (Fig. 3) in the periodicity of increment deposition in the natural environment, Fig. 8 pro-

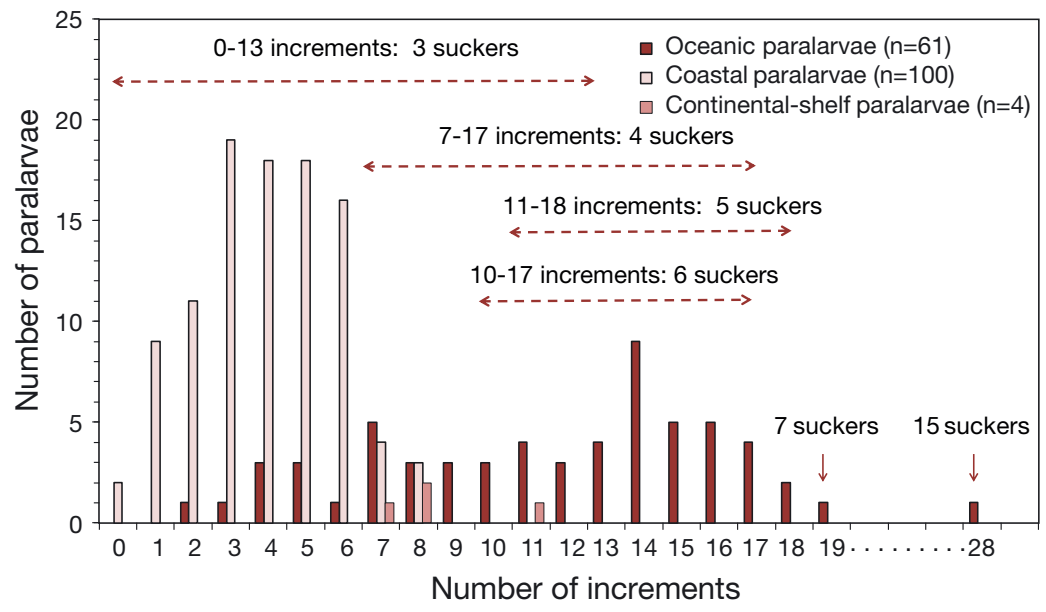

Fig. 7. Number of coastal and oceanic Octopus vulgaris paralarvae by number of growth increments in their beaks. Arrows indicate the number of suckers per range of increments. 3 suckers, $\mathrm{n}=117 ; 4$ suckers, $\mathrm{n}=26$; 5 suckers, $\mathrm{n}=9 ; 6$ suckers, $\mathrm{n}=7 ;>6$ suckers, $\mathrm{n}=2$

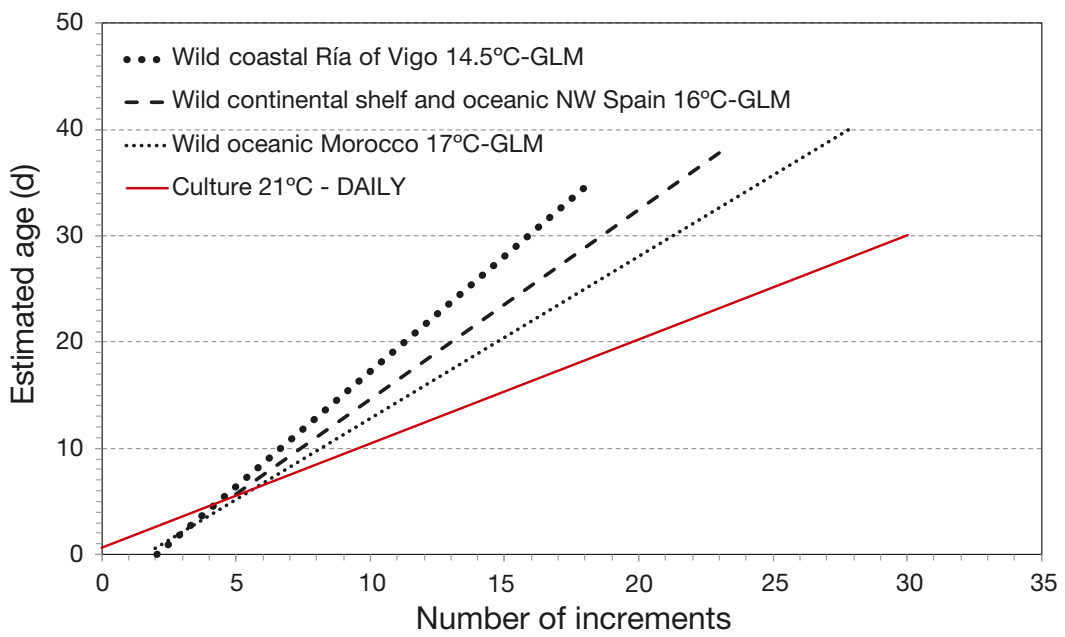

Fig. 8. General linear models (GLMs) for age adjustment of wild Octopus vulgaris paralarvae based on the number of growth increments in the beak, considering the effect of temperature in the increment deposition. Thick dotted line: model with $14.5^{\circ} \mathrm{C}$ as the mean temperature for coastal paralarvae (Ría of Vigo). Dashed line: model with $16^{\circ} \mathrm{C}$ as the mean temperature for paralarvae from oceanic and continental waters off NW Spain. Thin dotted line: model with $17^{\circ} \mathrm{C}$ as the mean temperature for oceanic paralarvae off Morocco. Red line: adjustment of cultured data at $21^{\circ} \mathrm{C}$ (daily deposition, optimal culture conditions)

vides the GLM simulation for the mean temperatures where coastal, continental-shelf and oceanic paralarvae were respectively caught: $14.5^{\circ} \mathrm{C}$ for the coastal area (range: $13.00-16.20$ ), $17^{\circ} \mathrm{C}$ for oceanic waters off Morocco (range: $11.70-21.50$ ) and $16^{\circ} \mathrm{C}$ for the oceanic and continental waters off NW Spain (range: 12.03-19.16). Table 2 shows mean ages obtained for each NI and each temperature group. 
Table 2. Mean ages (in days) obtained for each number of growth increments (NI) in the beaks of wild Octopus vulgaris paralarvae using a general linear model (GLM) simulation for mean temperatures where paralarvae were caught. Larvae originated from coastal waters at the Ría of Vigo, continental shelf and oceanic waters off NW Spain, and from oceanic waters off Morocco

\begin{tabular}{|c|c|c|c|}
\hline NI & $\begin{array}{c}\text { Age } \\
\text { GLM } 14.5^{\circ} \mathrm{C} \\
\text { Coastal } \\
\text { (Ría of Vigo) }\end{array}$ & $\begin{array}{c}\text { Age } \\
\text { GLM } 16^{\circ} \mathrm{C} \\
\text { Shelf-oceanic } \\
\text { (NW Spain) }\end{array}$ & $\begin{array}{c}\text { Age } \\
\text { GLM } 17^{\circ} \mathrm{C} \\
\text { Oceanic } \\
\text { (Morocco) }\end{array}$ \\
\hline 1 & -2.3 & - & - \\
\hline 2 & -0.1 & - & 0.6 \\
\hline 3 & 2.1 & - & 2.2 \\
\hline 4 & 4.2 & - & 3.7 \\
\hline 5 & 5.8 & 5.7 & 4.4 \\
\hline 6 & 8.1 & - & 6.7 \\
\hline 7 & 9.6 & 8.9 & 7.5 \\
\hline 8 & 12.2 & 10.5 & - \\
\hline 9 & - & 12.5 & - \\
\hline 10 & - & 14 & 12.8 \\
\hline 11 & - & 16.2 & - \\
\hline 12 & - & 17.3 & - \\
\hline 13 & - & 19.7 & 16.7 \\
\hline 14 & - & 21.1 & 18.7 \\
\hline 15 & - & 23.5 & 19.7 \\
\hline 16 & - & 25.3 & 21.6 \\
\hline 17 & - & 27.1 & 23.5 \\
\hline 18 & - & 28.4 & - \\
\hline 19 & - & - & 25.8 \\
\hline 28 & - & - & 40.3 \\
\hline
\end{tabular}

\section{DISCUSSION}

The anterior pigmented region in paralarvae beaks has been previously used for age estimation in early stages of Octopus vulgaris (Perales-Raya et al. 2014b, Franco-Santos et al. 2016, Garrido et al. 2016a), and Franco-Santos \& Vidal (2014) provided a morphological description of the beaks of paralarvae of several squid species, but the relationship between beak parts (rostrum, hood, lateral walls, shoulder) has not been addressed before. In contrast with adult beaks, transparency of this region in early developmental stages allowed us to observe the increments in the lateral surface of the rostrum, and preparation of RSS (following Perales-Raya et al. 2010) is not necessary in paralarvae. Increments used in adult RSS of octopuses (Perales-Raya et al. 2014a,b) and squids (Liu et al. 2015, Fang et al. 2016, Hu et al. 2016) are in fact the same increments as those in the rostrum surface of the paralarvae. The DIC-Nomarski technology also facilitated observation of different planes of the beak. Variability obtained in the reading precision (CV) of paralarval beaks is related to the high values obtained in some young individuals (5-8 increments), where a difference of 1 increment increases the CV. Precision is highly influenced by the species and the nature of the structure to be quantified (Campana 2001), and therefore any target level of $\mathrm{CV}$ for ageing studies also depends on the reading complexity of the structure.

Influence of temperature in increment deposition was evident at $14^{\circ} \mathrm{C}$ (Fig. 3), where paralarvae required more than $1 \mathrm{~d}$ for the deposition of each increment. The presence of an endogenous circadian rhythm was shown at $21^{\circ} \mathrm{C}$ by Meisel et al. (2003). Endogenous rhythms are common in marine organisms, but other factors may mask or reinforce the endogenous rhythm, which is synchronized at an early age with photo-periodicity or other external daily factors (Morales-Nin 1992). In fish otoliths, no evidence was found that increment numbers vary between temperature levels, except where low temperature has resulted in cessation of fish growth (Campana \& Neilson 1985). Oyadomari \& Auer (2007) reported that fish larvae with lower growth rates in the laboratory could not be aged as accurately by otolith analysis. Environmental conditions, transmitted through the physiology of the fish, affect the otolith growth rate, but increment periodicity may be disrupted only in extreme cases of physiological stress Morales-Nin (2000). Body weight and beak WRA of octopus paralarvae at $14^{\circ} \mathrm{C}$ (at any diet) showed a very low growth and higher variability when compared with cultured paralarvae at $21^{\circ} \mathrm{C}$ and wild paralarvae of the same ages (NI in wild individuals), both groups showing similar trends in WRA growth, although wild paralarvae showed smaller WRA sizes than paralarvae reared at $21^{\circ} \mathrm{C}$ (Fig. 6). Wild specimens inhabit areas with mean temperatures $<21^{\circ} \mathrm{C}$, and therefore their growth could be affected by temperature, as reported for fish planktonic larvae (Pomacentrus coelestis), for which water temperature explained approximately $30 \%$ of the growth variation, contrary to diet (zooplankton abundance), which explained only $3.5 \%$ (Meekan et al. 2003). Temperature controls $\mathrm{H}^{+}$ion availability in bicarbonate-buffered systems; therefore, this is an important control of otolith growth (Morales-Nin 2000), and beak growth might also be affected.

The adverse low temperature in the laboratory can lead to stressful conditions and slower growth, thus inducing slower increment deposition. We should not disregard the possibility that slow growth promotes very thin increments, even overlapping ones, which may also result in age underestimation. In contrast, paralarvae grown in optimal rearing conditions $\left(21^{\circ} \mathrm{C}\right.$, 
after Hamasaki \& Morioka 2002) or in wild environments may be less affected by this physiological stress, and increment deposition may not be disrupted. In natural environment, temperature fluctuations, even if they are experienced through vertical migrations (Fortier \& Leggett 1983), would be expected, reinforcing the endogenous daily cycle and thus producing more clear and regularly-spaced increments in wild-caught larvae than in laboratoryreared specimens (Campana \& Neilson 1985). Vertical migrations reported in wild paralarvae of $O$. vulgaris (Roura 2013, Roura et al. 2016) may emphasise their daily cycle deposition in the natural environment, as clear increments were observed in most of the individuals analysed. Moreover, $14^{\circ} \mathrm{C}$ in the wild may not be as adverse as under culture conditions, since this temperature and even lower are common in coastal upwelling areas where the paralarvae hatch and live during their first days of life (Roura et al. 2016). In addition, these cold waters harbour rich zooplankton communities that provide diverse and nutritious prey for the early hatchlings (Roura et al. 2012, Roura 2013, Olmos-Pérez et al. 2017). Assuming daily increments in wild octopus paralarvae, the mean increments and the number of suckers recorded in this study for coastal, continental-shelf and oceanic waters (Fig. 7, Table 3) support the hypothesis of the oceanic strategy displayed by $O$. vulgaris paralarvae that are dispersed far from the shelf (Roura et al. 2016). The youngest oceanic paralarvae with 2-4 increments (i.e. 2-4 d old) caught in Morocco were dispersed far from the coast by the strong upwelling filament recorded off the NW African coast during the CAIBEX-III survey (Sangrà et al. 2015). This upwelling filament was $120 \mathrm{~km}$ wide, $150 \mathrm{~m}$ deep and stretched more than $200 \mathrm{~km}$ offshore, thus transporting recently hatched paralarvae from the coast that were growing within the filament, as evidenced from Fig. 7.

Paralarvae caught in the oceanic waters of NW Spain and Morocco shared the same haplotypes of the cytochrome c oxidase subunit I (Roura 2013), despite the fact that both populations grow in upwelling systems separated by more than $2000 \mathrm{~km}$ and adults exhibit evident morphological differences (Amor et al. 2017). The zooplankton availability in these nutrient-rich upwelled waters (Hernández-León et al. 2007, Roura 2013) probably provides good food conditions for paralarval growth, and we consider that the increments counted in both upwelling regions can be compared directly. Indeed, the differences observed between the paralarvae captured off NW Spain (up to 5 suckers and 18 increments or days) and Morocco (up to 15 suckers and 28 increments or days), were attributed to the different oceanographic conditions in both surveys and had little to do with the temperatures recorded (Table 3). During the survey off NW Spain (CAIBEX-I), there was no well-developed filament as in Morocco (CAIBEX-III), and the only samples collected in the open ocean were at the end of a short upwelling pulse (Roura 2013). This short upwelling pulse, however, was strong enough to transport paralarvae as young as $5 \mathrm{~d}$ old (with only 3 suckers per arm, Table 3) from the coast to the continental slope $\sim 60 \mathrm{~km}$ offshore (samples S1-S7, Fig. 1).

Previous studies have evaluated the influence of temperature on the embryonic development and planktonic duration of $O$. vulgaris in temperate regions (e.g. Nande et al. 2017), and used it to predict hatching and settlement patterns (Katsanevakis \& Verriopoulos 2006). In a similar fashion, and considering that temperature influences the initial growth phase of $O$. vulgaris (Semmens et al. 2004), we evaluated the possible influence of temperature on the increment deposition of wild paralarvae (Fig. 8, Table 2), by means of a GLM built with the data obtained in captivity. By doing so and using the mean temperatures at capture of the wild paralarvae from different ecosystems (coast, shelf and oceanic from NW Spain and oceanic from Morocco), we estimated the age of the paralarvae assuming that NI was temperature dependent (Table 1b). This model is an approximation to adjust NI of wild paralarvae assum-

Table 3. Details of the Octopus vulgaris paralarvae collected off the coasts of NW Spain (2015-2016) and continental shelf and ocean off NW Spain and Morocco in 2009. NI: number of growth increments

\begin{tabular}{|lccccccc|}
\hline $\begin{array}{l}\text { Atlantic } \\
\text { area }\end{array}$ & Water & $\mathrm{n}$ & $\begin{array}{c}\text { No. of } \\
\text { suckers }\end{array}$ & NI & $\begin{array}{c}\text { Temperature } \\
\left({ }^{\circ} \mathrm{C}\right)\end{array}$ & $\begin{array}{c}\text { Depth } \\
(\mathrm{m})\end{array}$ & $\begin{array}{c}\text { Distance to } \\
\text { coast }(\mathrm{km})\end{array}$ \\
\hline NW Spain & Coastal & 100 & 3 & $0-8$ & $13.00-16.20$ & $18-20$ & $3-5$ \\
NW Spain & Continental shelf & 4 & $3-4$ & $7-11$ & $13.24-18.45$ & $136-147$ & $15-25$ \\
NW Spain & Oceanic & 37 & $3-5$ & $5-18$ & $12.03-19.16$ & $1940-3105$ & $62-75$ \\
Morocco & Oceanic & 24 & $3-15$ & $2-28$ & $11.70-21.50$ & $787-3110$ & $50-171$ \\
\hline
\end{tabular}


ing the influence of cold temperatures in the increment deposition. Consequently, caution should be taken, as the influence of temperature in the wild is not demonstrated and the high dispersion of planktonic paralarvae and their movements along upwelling water masses of different temperatures may result in deviation of the considered thermal mean values.

Extrapolation of results from rearing conditions to the natural environment is a complicated issue, since there are many biotic/abiotic natural conditions that are not easily emulated in captivity (e.g. pressure, temperature and light gradients, zooplankton communities). Nevertheless, further analyses of temperatures between the optimal $\left(21^{\circ} \mathrm{C}\right)$ and cold temperature $\left(14^{\circ} \mathrm{C}\right)$ with zooplankton-based diets are desirable to provide conclusions about the effect of temperature on the increment deposition of common octopus paralarvae.

Acknowledgements. This study was funded by Spanish Government under Projects OCTOWELF (Ref. AGL201349101-C2) and CAIBEX (CTM2007-66408-C02). Most of the authors of this paper participate to the COST network, Action FA1301 (CephsInAction) focussing on cephalopod welfare. We are indebted to the captain, crew and technicians of RV 'Sarmiento de Gamboa' for their assistance in collecting the zooplankton samples and hydrographical data during the project, as well as the staff of the Oceanographic Center of Vigo (IEO) for their assistance in the culture experiments and wild paralarvae captures. We thank the Parque Nacional das Illas Atlanticas (Galicia, Spain) for collaborating with us. Thanks also to Dr. Francisco J. Abascal (Oceanografic Center of Canaries-IEO) for his valuable assistance in performing the GLM.

\section{LITERATURE CITED}

Amor MD, Norman MD, Roura A, Leite TS and others (2017) Morphological assessment of the Octopus vulgaris species complex evaluated in light of molecular-based phylogenetic inferences. Zool Scr 46:275-288

Arístegui J, Barton ED, Álvarez-Salgado XA, Santos AMP and others (2009) Sub-regional ecosystem variability in the Canary Current upwelling. Prog Oceanogr 83:33-48

Balguerías E, Quintero ME, Hernández-González CL (2000) The origin of the Saharan Bank cephalopod fishery. ICES J Mar Sci 57:15-23

Boyle PR, Rodhouse PG (2005) Cephalopods. Ecology and fisheries. Blackwell Publishing, Oxford

Campana SE (2001) Accuracy, precision and quality control in age determination, including a review of the use and abuse of age validation methods. J Fish Biol 59:197-242

Campana SE, Neilson JD (1985) Microstructure of fish otoliths. Can J Fish Aquat Sci 42:1014-1032

Castellanos-Martínez S, Gestal C (2013) Pathogens and immune response of cephalopods. J Exp Mar Biol Ecol 447:14-22
Chang WYB (1982) A statistical method for evaluating the reproducibility of age determination. Can J Fish Aquat Sci 39:1208-1210

Fang Z, Li J, Thompson K, Hu F, Chen X, Liu B, Chen Y (2016) Age, growth, and population structure of the red flying squid (Ommastrephes bartramii) in the North Pacific Ocean, determined from beak microstructure. Fish Bull 114:34-45

Fiorito G, Affuso A, Basil J, Cole A and others (2015) Guidelines for the care and welfare of cephalopods in research-a consensus based on an initiative by CephRes, FELASA and the Boyd Group. Lab Anim 49: $1-90$

Fortier L, Leggett WC (1983) Vertical migrations and transport of larval fish in a partially mixed estuary. Can J Fish Aquat Sci 40:1543-1555

Fox J, Weisberg S (2011) Multivariate linear models in R. An $\mathrm{R}$ companion to applied regression, 2nd edn. SAGE Publications, Thousand Oaks, CA

Franco-Santos RM, Vidal EAG (2014) Beak development of early squid paralarvae (Cephalopoda: Teuthoidea) may reflect an adaptation to a specialized feeding mode. Hydrobiologia 725:85-103

Franco-Santos RM, Perales-Raya C, Almansa E, Detroch M, Garrido D (2016) Beak microstructure analysis as a tool for identifying stress sources during culture of Octopus vulgaris paralarvae. Aquacult Res 47:3001-3015

* Garrido D, Navarro JC, Perales-Raya C, Nande M and others (2016a) Fatty acid composition and age estimation of wild Octopus vulgaris paralarvae. Aquaculture 464: 564-569

Garrido D, Martín VM, Rodríguez C, Iglesias J and others (2016b) Meta-analysis approach to the effects of live prey on the growth of Octopus vulgaris paralarvae under culture conditions. Rev Aquacult (in press), doi:10.4111/raq. 12142

Hamasaki K, Morioka T (2002) Effects of temperature on egg incubation period, and paralarval survival and growth of common octopus, Octopus vulgaris reared in the laboratory. Suisan Zoshoku 50:407-413

Hastie TJ, Pregibon D (1992) Generalized linear models. In: Chambers SJM, Hastie TJ (eds) Statistical models. Wadsworth \& Brooks/Cole, Pacific Grove, CA, p 195-248

*Hernández-León S, Gomez M, Arístegui J (2007) Mesozooplankton in the Canary Current System: the coastalocean transition zone. Prog Oceanogr 74:397-421

Hernández-López JL, Castro-Hernández JJ, HernándezGarcía V (2001) Age determined from the daily deposition of concentric rings on common octopus (Octopus vulgaris) beaks. Fish Bull 99:679-684

Hochner B (2008) Octopuses. Curr Biol 18:R897-R898

*Hu G, Fang Z, Liu B, Yang D, Chen X, Chen Y (2016) Age, growth and population structure of jumbo flying squid Dosidicus gigas off the Peruvian Exclusive Economic Zone based on beak microstructure. Fish Sci 82:597-604

Iglesias J, Fuentes L (2014) Octopus vulgaris. Paralarval culture. In: Iglesias J, Fuentes L, Villanueva R (eds) Cephalopod culture. Springer, New York, NY, p 427-450

Iglesias J, Pazos G, Fernández J, Sánchez FJ and others (2014) The effects of using crab zoeae (Maja brachydactyla) on growth and biochemical composition of Octopus vulgaris (Cuvier 1797) paralarvae. Aquacult Int 22: 1041-1051

Iglesias P, Picón P, Nande M, Lago MJ, Otero JJ, Trujillo V, Iglesias J (2016) Effect of low salinity on survival and 
ingested food of the common octopus, Octopus vulgaris Cuvier, 1797. J Appl Aquacult 28:267-271

Katsanevakis S, Verriopoulos G (2006) Seasonal population dynamics of Octopus vulgaris in the eastern Mediterranean. ICES J Mar Sci 63:151-160

Liu BL, Chen XJ, Chen Y, Hu GY (2015) Determination of squid age using upper beak rostrum sections: technique improvement and comparison with the statolith. Mar Biol 162:1685-1693

Mangold K (1983) Octopus vulgaris. In: Boyle PR (ed) Cephalopod life cycles, Vol 1. Species accounts. Academic Press, London, p 335-364

Mangold K, Boletzky SV (1973) New data on reproductive biology and growth of Octopus vulgaris. Mar Biol 19: $7-12$

Media Cybernetics (2008) Package Image Pro Plus 6.3. www.mediacy.com

Meekan MG, Carleton JH, McKinnon AD, Flynn K, Furnas M (2003) What determines the growth of tropical reef fish larvae in the plankton: food or temperature? Mar Ecol Prog Ser 256:193-204

Meisel DV, Byrne RA, Kuba M, Griebel U, Mather JA (2003) Circadian rhythms in Octopus vulgaris. Coleoid cephalopods through time. Berl Paläobiol Abh 3:171-177

Morales-Nin B (1992) Determination of growth in bony fishes from otolith microstructure. Fish Tech Pap 322. FAO, Rome

Morales-Nin B (2000) Review of the growth regulation processes of otolith daily increment formation. Fish Res 46 : 53-67

Nande M, Iglesias J, Domingues P, Pérez M (2017) Effect of temperature on energetic demands during the last stages of embryonic development and early life of Octopus vulgaris (Cuvier, 1797) paralarvae. Aquacult Res 48: 1951-1961

Navarro JC, Monroig Ó, Sykes AV (2014) Nutrition as a key factor for cephalopod aquaculture. In: Iglesias J, Fuentes L, Villanueva R (eds) Cephalopod culture. Springer, Dordrecht, p 77-95

Norman MD, Finn JK, Hochberg FG (2016) Family Octopodidae. In: Jereb P, Roper CFE, Norman MD, Finn JK (eds) Cephalopods of the world. An annotated and illustrated catalogue of cephalopod species known to date. Vol 3. Octopods and vampire squids. FAO Species Catalogue for Fishery Purposes. FAO, Rome, p 36-215

Kolmos-Pérez L, Roura Á, Pierce GJ, Boyer S, González ÁF (2017) Diet composition and variability of wild Octopus vulgaris and Alloteuthis media (Cephalopoda) paralarvae: a metagenomic approach. Front Physiol, doi: 10.3389/fphys.2017.00321

Otero J (2006) Ecología del pulpo común (Octopus vulgaris Cuvier, 1797) en un área de afloramiento costero (Galicia, NE Atlántico). PhD thesis, University of Vigo

Oyadomari JK, Auer NN (2007) Influence of rearing temperature and feeding regime on otolith increment deposition in larval ciscoes. Trans Am Fish Soc 136:766-777

Perales-Raya C, Bartolomé A, García-Santamaría MT, Pascual-Alayón P, Almansa E (2010) Age estimation obtained from analysis of octopus (Octopus vulgaris Cuvier,

Editorial responsibility: Stephen Wing,

Dunedin, New Zealand
1797) beaks: improvements and comparisons. Fish Res 106:171-176

Perales-Raya C, Jurado A, Bartolomé A, Duque V, Carrasco N, Fraile-Nuez E (2014a) Age of spent Octopus vulgaris and stress mark analysis using beaks of wild individuals. Hydrobiologia 725:105-114

*Perales-Raya C, Almansa E, Bartolomé A, Felipe BC and others (2014b) Age validation in Octopus vulgaris beaks across the full ontogenetic range: beaks as recorders of life events in octopuses. J Shellfish Res 33:481-493

R Core Team (2016) R: a language and environment for statistical computing. R Foundation for Statistical Computing, Vienna. www.r-project.org/

* Reis DB, García-Herrero I, Riera R, Felipe BC and others (2015) An insight on Octopus vulgaris paralarvae lipid requirements under rearing conditions. Aquacult Nutr 21:797-806

Roura A (2013) Ecology of planktonic cephalopod paralarvae in coastal upwelling systems. PhD thesis, University of Vigo

* Roura Á, González ÁF, Redd K, Guerra Á (2012) Molecular prey identification in wild Octopus vulgaris paralarvae. Mar Biol 159:1335-1345

Roura A, Álvarez-Salgado XA, González AF, Gregori M, Rosón G, Otero J, Guerra A (2016) Life strategies of cephalopod paralarvae in a coastal upwelling system (NW Iberian Peninsula): insights from zooplankton community and spatio-temporal analyses. Fish Oceanogr 25: 241-258

Sangrà P, Troupin C, Barreiro-González B, Desmond Barton E, Orbi A Arístegui J (2015) The Cape Ghir filament system in August 2009 (NW Africa). J Geophys Res Oceans 120:4516-4533

* Semmens JM, Pecl GT, Villanueva R, Jouffre D, Sobrino I, Wood JB, Rigby PR (2004) Understanding octopus growth: patterns, variability and physiology. Mar Freshw Res 55:367-377

SPSS Inc (2008) SPSS statistics for Windows, Version 17.0 released 2008. Chicago, IL

Sweeney MJ, Roper CFE, Mangold K, Clarke MR, Boletzky SV (1992) 'Larval' and juvenile cephalopods: a manual for their identification. Smithsonian Contributions to Zoology No. 513. Smithsonian Institution Press, Washington, DC

Vaz-Pires P, Seixas P, Barbosa A (2004) Aquaculture potential of the common octopus (Octopus vulgaris Cuvier, 1797) a review. Aquaculture 238:221-238

Vidal EAG, Andrade JP, Villanueva R, Gleadall IG and others (2014) Cephalopod culture: current status of main biological models and research priorities. Adv Mar Biol 67:1-98

V Villanueva R (1995) Experimental rearing and growth of planktonic Octopus vulgaris from hatching to settlement. Can J Fish Aquat Sci 52:2639-2650

Villanueva R, Norman MD (2008) Biology of the planktonic stages of benthic octopuses. Oceanogr Mar Biol Annu Rev 46:105-202

Xavier JC, Allcock AL, Cherel Y, Lipinski MR and others (2015) Future challenges in cephalopod research. J Mar Biol Assoc UK 95:999-1015

Submitted: March 13, 2017; Accepted: May 30, 2017 Proofs received from author(s): August 11, 2017 